\title{
Investigation into the current stage of BIM application in China's AEC industries
}

\author{
R. Jin, L. Tang \& K. Fang \\ Department of Architecture and Built Environment, \\ University of Nottingham Ningbo China, China
}

\begin{abstract}
Building Information Modelling (BIM), the movement in the architectural, engineering, and construction (AEC) industries worldwide, is pushing AEC firms to adopt BIM technologies in multiple engineering design fields and project management. China, the world's largest AEC market, is currently undergoing a growing demand on BIM utilization along with recently published governmental policies to enhance the BIM adoption. Despite the general trend of BIM implementation, there are some challenges of implementing BIM in China's local AEC industries. This paper is aimed at investigating the current stage of BIM practice in China. Through literature review of BIM application in China and overseas, followed by a questionnaire-based survey to an international engineering firm in China, both qualitative and quantitative information has been collected to analyse the local BIM practice, the benefits and barriers of implementing BIM, and the future of BIM in China. The findings of the investigation provide the vision of BIM development in the next five to ten years in China, and recommendations on future BIM implementation.
\end{abstract}

Keywords: BIM, China, AEC, construction, questionnaire survey, policy, standards.

\section{Introduction}

Building Information Modelling (BIM), with which accurate virtual models of a building can be constructed digitally, is one of the most promising developments in the architectural, engineering, and construction (AEC) industries (Eastman et al. [1]). The benefits of BIM application include, but are not limited to, accurate eometrical representation of building elements, faster project process, improved 
design quality, better control of cost, environmental, and lifecycle data, better production quality (CRC Construction Innovation [2]).

China, the world's giant AEC market, is undergoing continuously increasing construction industry revenues from 2009 to 2013 with an average growth rate at $11.5 \%$, and accounted for $47.9 \%$ of the Asia-Pacific industry value (MarketLine [3]). MarketLine [3] expected that China would accelerate the growth of its construction industry to an average of $12.6 \%$ in the next five years. Although BIM technology has been applied in China's building industry since 2003, and is moving towards being the mainstream technology in the AEC industries, the current usage of BIM is still limited to design firms (He et al. [4]). According to He et al. [4], BIM will become the major breakthrough in China's building industry, but presently the BIM development is facing challenges such as the lack of well-developed standards and legislation, lack of interoperability among project team members, and difficulties of implementing BIM in the whole building lifecycle, etc.

This paper aims to explore the current stage of BIM implementation in China's AEC industries, through the literature review of BIM movement in developed countries (e.g. US and UK, etc.) and China, review of newly published BIM related policies in China both nationally and regionally, as well as existing studies conducted in China regarding the BIM market surveys. Furthermore, a questionnaire-based survey of an overseas engineering firm in China's regional office was analysed. Finally, the current BIM practice was discussed from the aspects of government, industry, and academia. Recommendations were provided in the end on the directions of future BIM research areas in China.

\section{Analysis of BIM movement in China}

\subsection{BIM implementation worldwide}

The global movement of BIM has motivated multiple countries and regions to implement BIM as the state-of-the-art technology in the AEC industries, with updated governmental policies, industrial standards, and the corresponding industry practices. Table 1 summarizes the recent movement of BIM in different countries or regions.

Table 1 provides an overview of how the national authorities have been supporting the development of BIM through either compulsory (e.g. UK) or incentive policies (e.g. Singapore).

The BIM practice varies in different countries or regions. For example, BIM adoption rate among contractors reached 50\% in North America compared to only $24 \%$ of the counterparts in Western Europe according to the 2010 SmartMarket Report of McGraw-Hill Construction [5]. Meanwhile 34\% of BIM users in Western Europe had over 5 years of experience, and that rate was only $18 \%$ in North America up to 2010 (McGraw-Hill Construction [5]). The most recent data from McGraw-Hill Construction [6] is indicating the fast increase of BIM usage worldwide. For instance, the percentage of contractors at high or very high BIM 
Table 1: Global map of BIM.

\begin{tabular}{|c|c|}
\hline $\begin{array}{l}\text { Country/ } \\
\text { Region }\end{array}$ & BIM movement \\
\hline Singapore & $\begin{array}{l}\text { The Building and Construction Authority (BCA) announced that BIM } \\
\text { would be introduced for architectural submission by } 2013 \text {, structural and } \\
\text { M\&E submissions by } 2014 \text { and eventually for plan submissions of all } \\
\text { projects with a gross floor area of more than 5,000 square metres by } 2015 \text {. } \\
\text { Government financial incentives are also provided to encourage BIM } \\
\text { application. }\end{array}$ \\
\hline Hong Kong & $\begin{array}{l}\text { HKIBIM was established in } 2009 \text {. The Hong Kong Housing Authority } \\
\text { set the full gear in } 2014 / 2015 \text {. }\end{array}$ \\
\hline Canada & BIM Council was founded in late 2008. \\
\hline UK & $\begin{array}{l}\text { Construction Project Information Committee (CPIC) adopted US } \\
\text { National BIM Standard Project Committee, and required the full BIM } \\
\text { implementation by } 2016 \text {. }\end{array}$ \\
\hline US & $\begin{array}{l}\text { The Federal Government announced a five year programme, which has } \\
\text { encouraged BIM adoption elsewhere and make recommendations on } \\
\text { their lessons. }\end{array}$ \\
\hline
\end{tabular}

implementation levels would be increased from an average value of $31.8 \%$ in 2013 to $63.1 \%$ in 2015 in these ten countries (i.e. Japan, New Zealand, South Korea, Canada, UK, France, Australia, Germany, Brazil, and the US) according to the data provided by McGraw-Hill Construction [6].

\subsection{BIM industry practice in China}

China's construction market has the potential to see immense benefits from BIM, but is restricted to its own structural obstacles (McGraw-Hill Construction [6]). According to the China Construction Industry Association's (CCIA) market survey in 2012 [7], less than $15 \%$ of a total of 388 Chinese contractors indicated that they have adopted BIM, although $55 \%$ of them stated that they had heard of BIM. This rate is low compared to North America or Western Europe. Similar BIM market surveys had been conducted both in China and overseas in recent years focusing on industry practitioners' perceptions of BIM application. Table 2 summarizes and compares the results from three BIM market surveys in the UK and China.

Both similarities and differences from the three BIM market surveys summarized in Table 2 could be identified. Up to 2012, BIM has reached a certain level of application at the design stage or within the design firms in both UK and Shenzhen, the latter is one of the most economically active and BIM-leading city in China apart from Shanghai and Beijing. However, the application of BIM was still limited in post-design stages such as construction. The China BIM practice in design remained in testing stages targeted on smaller-size projects, as compared to a wider usage of BIM in the UK. Clients were considered the side that received the most benefits from BIM implementation in both the UK and Shenzhen, China, although general contractors may have slightly differed views. Project costs and 
Table 2: BIM market surveys.

\begin{tabular}{|c|c|c|c|}
\hline Country & $\begin{array}{l}\text { UK survey from Eadie et } \\
\text { al. [8] }\end{array}$ & $\begin{array}{l}\text { China survey from } \\
\text { CCIA [7] }\end{array}$ & $\begin{array}{l}\text { China survey from } \\
\text { Shenzhen Exploration \& } \\
\text { Design Association } \\
\text { (SZEDA [9]) }\end{array}$ \\
\hline Survey year & 2012 & 2012 & 2012 \\
\hline Survey pool & $\begin{array}{l}\text { In total } 92 \text { BIM } \\
\text { organizations in the UK, } \\
\text { with a wide coverage of } \\
\text { professions including } \\
\text { architect, engineers, } \\
\text { facility manager, client, } \\
\text { layers, etc. }\end{array}$ & $\begin{array}{l}\text { In total } 388 \text { major } \\
\text { large-size and highly- } \\
\text { qualified general } \\
\text { contractors within } 24 \\
\text { provinces of China. }\end{array}$ & $\begin{array}{l}\text { In total } 30 \text { responses from } \\
\text { mainly engineering design } \\
\text { firms in Shenzhen, one of } \\
\text { the BIM-leading cities in } \\
\text { China. }\end{array}$ \\
\hline $\begin{array}{l}\text { BIM } \\
\text { implementation } \\
\text { level }\end{array}$ & $\begin{array}{l}\text { Over half of the survey } \\
\text { participants reported the } \\
\text { "often" usage of BIM in } \\
\text { design and } \\
\text { preconstruction stages, but } \\
\text { less application on } \\
\text { construction and operation } \\
\text { stages. }\end{array}$ & $\begin{array}{l}\text { Most firms stayed in } \\
\text { the "heard-of" stage, } \\
\text { with limited } \\
\text { application of BIM. }\end{array}$ & $\begin{array}{l}\text { Over } 90 \% \text { of design firms } \\
\text { had heard of BIM, but } \\
54 \% \text { of them claimed that } \\
\text { BIM application stayed in } \\
\text { the experimental stage in } \\
\text { small-size projects. }\end{array}$ \\
\hline $\begin{array}{l}\text { Perceptions on } \\
\text { which party } \\
\text { received the } \\
\text { most benefits } \\
\text { from BIM }\end{array}$ & $\begin{array}{l}\text { Clients received the most } \\
\text { financial benefits, } \\
\text { followed by facility } \\
\text { managers, software } \\
\text { vendors, general } \\
\text { contractors, building } \\
\text { users, etc. }\end{array}$ & $\begin{array}{l}\text { Over } 30 \% \text { of surveyed } \\
\text { contractors believed } \\
\text { that contractors would } \\
\text { have the most benefit } \\
\text { from BIM. }\end{array}$ & $\begin{array}{l}\text { Totally } 96 \% \text { of survey } \\
\text { participants considered } \\
\text { client/owner is the party } \\
\text { that received the most } \\
\text { benefit, followed by } \\
\text { contractors }(19 \%) \text {, } \\
\text { consultants }(15 \%) \text {, and } \\
\text { design firms }(12 \%) \text {. }\end{array}$ \\
\hline $\begin{array}{l}\text { BIM impact } \\
\text { measurements }\end{array}$ & $\begin{array}{l}\text { Overall cost and cost of } \\
\text { changes were top ranked } \\
\text { measurements. }\end{array}$ & $\begin{array}{l}\text { Construction } \\
\text { visualization, cost } \\
\text { control, and decreased } \\
\text { cost. }\end{array}$ & $\begin{array}{l}\text { Design feasibility and } \\
\text { reductions in design } \\
\text { changes. }\end{array}$ \\
\hline $\begin{array}{l}\text { BIM } \\
\text { collaboration }\end{array}$ & $\begin{array}{l}\text { Collaboration was } \\
\text { considered key to } \\
\text { successful BIM. }\end{array}$ & $\begin{array}{l}\text { Contractors reported } \\
\text { limited collaboration } \\
\text { with clients. }\end{array}$ & $\begin{array}{l}\text { Project coordination and } \\
\text { collaboration was } \\
\text { considered the most } \\
\text { urgent needs in BIM } \\
\text { implementation. }\end{array}$ \\
\hline $\begin{array}{l}\text { Challenges in } \\
\text { BIM } \\
\text { implementation }\end{array}$ & $\begin{array}{l}\text { Lack of expertise within } \\
\text { the project team and } \\
\text { organizations. }\end{array}$ & N/A. & $\begin{array}{l}\text { Lack of BIM talents, BIM } \\
\text { software not well } \\
\text { developed, hardship in } \\
\text { changing the company } \\
\text { management, lack of BIM } \\
\text { industry standard. }\end{array}$ \\
\hline
\end{tabular}

costs caused by changes were the major concern when implementing BIM, although it also depends on the role of the project player. For example, design firms would consider more on their own design feasibility and changes of design. Regarding the challenges encountered in further implementing BIM, both the UK and Shenzhen surveys indicated that the lack of BIM expertise or talents was one of the major barriers. This would indicate the necessity of BIM training to industry professionals. Though the BIM adoption rate appeared low in 2012 among the major Chinese contractors, both surveys from CCIA [7] and SZEDA [9] conveyed the information that most survey participants showed interests in BIM and a 
willingness to invest in BIM technologies. The newly released survey report from Shanghai Construction Trade Association (SCTA) and Luban Consulting [10] showed that up to the end of $2014,67 \%$ of surveyed construction firms nationwide had started using BIM, and over $10 \%$ of clients had used BIM in over $50 \%$ of their projects. The highly increased adoption rate of BIM in China's construction industry could be partly due to the requirements and motivations driven by governmental policies and industry standards.

\subsection{BIM policies and standards in China}

Governmental policy works as a driver to move the BIM practice forward in China's construction industry. BIM related policies and standards have been undergoing fast movement during the national $12^{\text {th }}$ Five-Year Plan period (20112015). The recent movements of BIM related governmental policies from the Ministry of Housing and Urban-Rural Construction are listed in Table 3.

Table 3: National BIM policies in China.

\begin{tabular}{|c|c|c|}
\hline Time & Policy & Details \\
\hline $\begin{array}{l}\text { May } \\
2011\end{array}$ & $\begin{array}{l}\text { The 2011-2015 } \\
\text { Development } \\
\text { Guideline for the } \\
\text { construction industry } \\
\text { digitalization }\end{array}$ & $\begin{array}{l}\text { To achieve the digitalization goal within } \\
\text { construction firms during the } 12^{\text {th }} \text { Five-Year } \\
\text { Plan, to move forward the BIM implementation } \\
\text { through the establishment of BIM standards, and } \\
\text { to have a group of construction firms equipped } \\
\text { world-class digital technologies. }\end{array}$ \\
\hline $\begin{array}{l}\text { January } \\
2012\end{array}$ & $\begin{array}{l}\text { The announcement of } \\
\text { publishing the } 2012 \\
\text { Engineering and } \\
\text { Construction Standards }\end{array}$ & $\begin{array}{l}\text { This was the official launch of the Chinese BIM } \\
\text { standards, which consisted of five aspects: BIM } \\
\text { application, BIM digital data storage, BIM file } \\
\text { turn-over, model categorization and codes, as } \\
\text { well as industrial digital information modelling } \\
\text { standards. }\end{array}$ \\
\hline $\begin{array}{l}\text { August } \\
2013\end{array}$ & $\begin{array}{l}\text { Request for proposal } \\
\text { on BIM application in } \\
\text { the construction } \\
\text { industry }\end{array}$ & $\begin{array}{l}\text { Strategic objectives were established on BIM } \\
\text { application in public projects: } \\
\text { By } 2016 \text {, government-invested projects over } \\
20,000 \text { square metres and "green" buildings in } \\
\text { the provincial level should adopt BIM in both } \\
\text { design and construction stages; } \\
\text { By 2020, the industry guidelines for BIM } \\
\text { application and government policy systems } \\
\text { should be well-established. }\end{array}$ \\
\hline $\begin{array}{l}\text { July } \\
2014\end{array}$ & $\begin{array}{l}\text { Proposals on enhancing } \\
\text { the development and } \\
\text { improvement in the } \\
\text { construction industry }\end{array}$ & $\begin{array}{l}\text { To enhance the implementation of BIM in } \\
\text { project design, construction, and operation and } \\
\text { maintenance; to improve the overall project } \\
\text { outcome through BIM usage; and to actively } \\
\text { investigate the feasibility of replacing traditional } \\
\text { hardcopy drawings with digital files. }\end{array}$ \\
\hline
\end{tabular}

It could be indicated from Table 3 that China's national BIM policy has seen under active development in recent years from 2011 to 2014. At the beginning of the $12^{\text {th }}$ Five-Year Plan, BIM was proposed but with limited outline objectives. In 
2013, more clear visions were provided. By 2014, BIM was proposed to cover the whole building life cycle. Apart from that, replacing 2D drawings with BIM files was proposed in 2014. That would lead the trend of drawing digitalization in the next five to ten years in China's AEC industries, although there would be certain obstacles. For example, there are a large number of AEC firms who have been using the traditional 2D Computer Aided Design (CAD) that are facing the challenges of upgrading to BIM. Apart from that, there are also regional differences of BIM implementation considering China's large AEC market. The major metropolitan cities like Shanghai are leading the BIM application in the industry.

Apart from the national policy movement, regional BIM policies were also under development in 2014. As the geographic map illustrates in Figure 1, the eastern coast of China is in a much better economical condition compared to the western inland of China, and the major BIM active regions are also located on the eastern coast. Metropolitan areas like Beijing, Shanghai, Shenzhen and Guangzhou are all located on the eastern coast and have all published their own BIM policies. The BIM map is demonstrated in Figure 1. Compared to the eastern coast of China, other regions are less developed with BIM implementation. There is limited information of BIM movement in regions outside the eastern coast of China. Within the eastern coast as defined by the boundary line in Figure 1, Beijing, Shanghai and Canton Province, where cities of Guangzhou and Shenzhen are located, are leading the BIM standards and industry practice in their own subregions.

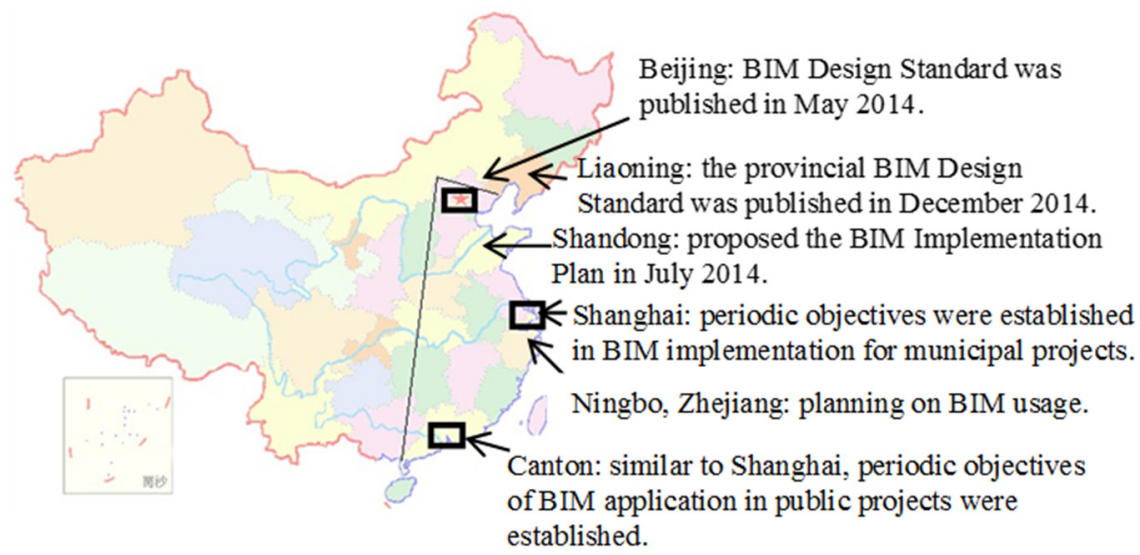

Figure 1: BIM Map of China.

The cities or provinces that established their BIM plans in Figure 1 all fall into the defined eastern coast region. Spreading from the three major BIM leading subregions - Beijing, Shanghai and Canton, surrounding cities or provinces are currently learning the experience from the sub-region's BIM centres. For example, provinces of Liaoning and Shandong, close to Beijing, are establishing their own BIM design standards or objectives. Ningbo, an international port city located in 
the Zhejiang Province to the south of Shanghai, is currently proposing the municipal $13^{\text {th }}$ Five-Year Plan (2015-2020) with BIM as one key topic. Shanghai serves as an example of how BIM could be started and implemented in the next five years for Ningbo. Therefore, it could be inferred that there are regional differences in BIM implementation levels. The BIM implementation-active cities or provinces are also the more economically developed sub-regions in China. The remaining areas in China are adopting BIM in a fast movement in the coming years throughout the establishment of BIM policies and standards.

\section{Questionnaire survey}

The rising AEC market in China has been attracting more and more international AEC firms to enter the Chinese market. Previous BIM surveys including CCIA [7], SZEDA [9], and Shanghai Construction Trade Association (SCTA) and Luban Consulting [10], recruited participants from Chinese industry practitioners, with limited information of international engineering firms in China. To gain a further picture of the current stage of BIM practice in China, especially within the AEC firms with international background, researchers adopted a questionnaire survey targeting the subject of building services. The survey participants were recruited from the Mechanical, Electrical, and Plumbing (MEP) department of an international engineering consultant company in Beijing. The headquarters of this company was located in London. It had around 200 staff in Beijing. Apart from the MEP department, it also had the structure, fire protection, façade etc. This company mainly involved large scale commercial projects and had adopted BIM in their projects. Therefore, this company was chosen as the target of the questionnaire survey. This survey was approved by the Research Ethics Office at the University of Nottingham Ningbo China to ensure that the human-subject related research activities met the research ethics requirements. In total 42 responses were received out of total 50 questionnaires sent during March, 2015. Survey questions mainly looked into the BIM familiarity and adoption, and user perception of BIM within the survey participants.

\subsection{Background of survey participants}

The background information in terms of trades and years of industry experience are summarized in Figure 2.

\subsection{BIM familiarity and adoption}

All the survey participants had heard of BIM in this survey. The 100\% BIM awareness within this survey pool could be due to the fact that this firm is equipped with the cutting edge AEC expertise and having employees with international background. However, it would be questionable to indicate that other Chinese local engineering firms within this region are all well aware of BIM. Among all the survey participants, $95 \%$ of them had not heard of BIM until 2010. It could be indicated that BIM was a new concept in China and most employees started learning BIM after 2010. The regular BIM training started in recent years within this firm and enriched the BIM knowledge of employees. 


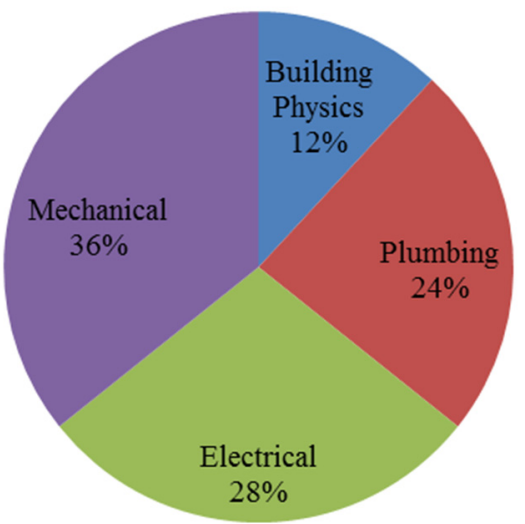

(a)

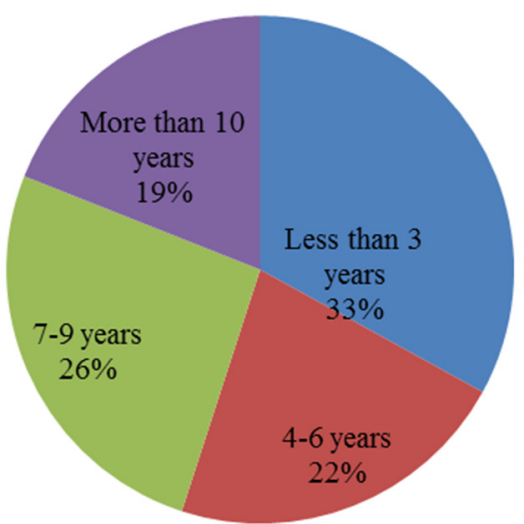

(b)

Figure 2: Background of survey participants. (a) Trade distribution of survey participants. (b) Work experience of survey participants.

Despite the high awareness of BIM within the survey pool, only half of them had ever used BIM in their projects. This is consistent with the findings from CCIA [7], which also indicated the low adoption rate of China's industry practitioners. When asked the frequency of BIM adoption in their projects, none of them reported a high adoption rate (between $31 \%$ and $60 \%$ of projects that they had been involved in), only $12 \%$ of them reported a moderate usage of BIM (15\%$30 \%$ adoption rate), leaving the majority $(88 \%)$ of survey participants stating that BIM had been used in less than $15 \%$ of their previous projects. Further investigation indicated that most BIM adopters barely used BIM to achieve 3D visualization. The further functions of BIM such as reducing design changes and improving team collaboration crossing trades or disciplines had not been fully displayed.

\subsection{User perception}

Survey participants were further asked their opinions of how BIM affects the whole AEC industry and the difficulties in learning a new BIM technology. The statistical results are displayed in Figure 3.

Although the majority (55\%) of participants perceived moderate impact of BIM in the industry, there were more participants considered BIM had negative impacts than those who claimed that BIM had a positive impact. It was further indicated from the survey that most employees were used to utilizing the traditional objectoriented CAD system rather than the newly emerged BIM tools. Cultural resistance could be one barrier of new BIM users. When asked the experience of learning a new BIM tool (e.g. Autodesk Revit), close to $75 \%$ of survey participants stated that it was difficult or very difficult to learn BIM. It could be inferred that an effective BIM train is important to enhance employees' learning of BIM. 


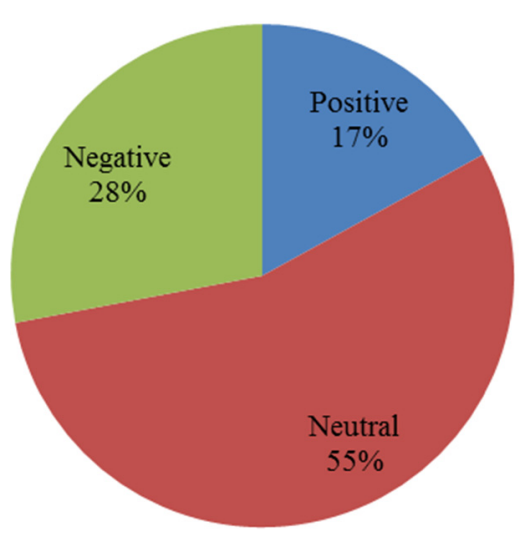

(a)

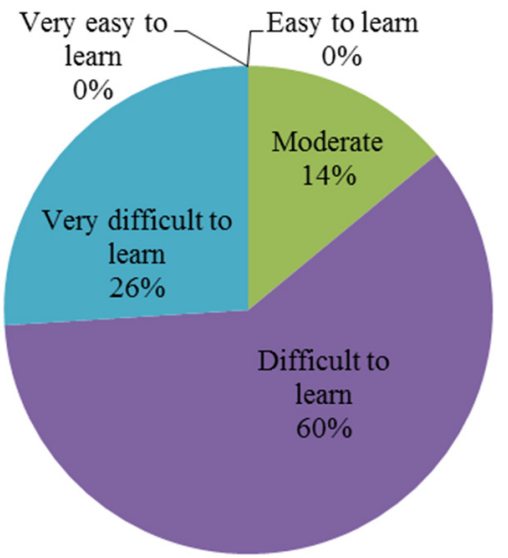

(b)

Figure 3: User perceptions on BIM usage. (a) User attitudes towards BIM. (b) User perception of learning BIM skills.

\section{Findings and discussion}

There would be different levels of knowing BIM within the industry practitioners. Having heard of BIM is the first stage of being a BIM user in the AEC industries. BIM training is an approach to transform an employee from only being aware of BIM to start adopting BIM. From the firm's perspective, it may undergo a long process from starting to use BIM at the explorative stage of applying BIM in smaller-sized projects to ultimately adopting BIM in all or the majority of projects. From the individual side, it is also a long process from starting to use BIM to being a frequent BIM adopter. Both external influences (e.g. the governmental policies) and the internal motivations (e.g. the firm's interests in adopting BIM and employees' attitudes towards digital technologies) impact the BIM implementation.

Although BIM has been realized of its power in enhancing project team collaboration as shown in the surveys of Eadie et al. [8] and SZEDA [9], the application of BIM in the real world may still be limited to 3D visualization and clash detection. There remains a large gap between proposed BIM application areas and its current implementation. Therefore, there is a high potential for BIM users to explore more functions of BIM, as BIM could be used not just as a tool, but also as a way of project delivery and business management. There are multiple approaches that BIM could be more widely used and applied beyond the 3D visualization level in the near future, for example, the compulsory requirements or incentive strategies from the governmental authorities to drive the BIM implementation starting from public projects, and training provided to industry practitioners.

Industry practitioners' views on BIM impact could vary depending on his or her own role and also the expertise level. Both surveys from Eadie et al. [8] and 
SZEDA [9] found out that the lack of BIM expertise or qualified personnel was one major challenge in implementing BIM, and this was further indicated by the survey in this study that most surveyed participants perceived BIM difficult to learn, despite of the fact this surveyed international engineering firm had leading technologies and experiences in China. It could be indicated that BIM training would be important in the coming years in order to provide more qualified BIM professionals in the AEC industries.

\section{Conclusion}

This study started from reviewing the BIM implementation in the global AEC industries, and also the recent BIM movement in China. Through comparisons of BIM market surveys between China and developed countries (i.e. UK), the current stage of BIM implementation in China was summarized and analysed in terms of BIM implementation level, perceptions of parties benefitting from BIM, impact measurements, BIM collaboration, and challenges encountered. The updated BIM related governmental policies and industry standards were reviewed. The BIM map of China was provided indicating the regional differences of BIM implementation in China. A follow-up questionnaire survey was conducted and analysed to provide the insight of the BIM implementation within an international engineering firm run in China. Similar to local Chinese AEC firms, the BIM adoption rate and utilization of BIM functions had a high potential in enhancement in the near future. China is a huge BIM market with BIM technology and related standards currently undergoing fast movement spreading from major BIM active cities or provinces. There is still a large potential for Chinese MEP engineers to increase the BIM usage in their projects. The newly released governmental policies and industry standards would drive the wider implementation of BIM in AEC practices.

\section{Recommendations for future research}

There was only one target company in this survey and the participant number could be enlarged. Therefore the result cannot fully represent the whole building services design area in China. Future market surveys would recruit more AEC firms to create a larger survey pool. Other disciplines apart from building services could be explored of the BIM implementation level. Deeper analysis, such as how the educational background and training experience would affect employees' perception on BIM, could be provided in the future.

\section{References}

[1] Eastman, C., Teicholz, P., Sacks, R. \& Liston, K., BIM Handbook, A Guide to Building Information Modeling For Owners, Managers, Designers, Engineers and Contractors, John Wiley \& Sons, Inc., Hoboken, New Jersey, p. 1, 2011. 
[2] CRC Construction Innovation, Adopting BIM for facilities management: Solutions for managing the Sydney Opera House, Cooperative Research Centre for Construction Innovation, Brisbane, Australia. 2007.

[3] MarketLine Industry Profile, Construction in China, Reference Code: 00992801, pp. 7-11, July 2014.

[4] He, Q., Qian, Li., Duan, Y. \& Li, Y., Current Situation and Barriers of BIM Implementation. Journal of Engineering Management, 26 (1), pp. 12-16, 2012.

[5] McGraw-Hill Construction, The Business Value of BIM in Europe, SmartMarket Report, Research \& Analytics, Bedford, MA, pp. 4-5, 2010.

[6] McGraw-Hill Construction. The Business Value of BIM for Construction in Major Global Markets, SmartMarket Report, Research \& Analytics, Bedford, MA, p. 10, 2014.

[7] China Construction Industry Association (CCIA), Research of BIM application in construction firms (1), Beijing: China Architecture \& Building Press, March, 2013.

[8] Eadie, R., Browne, M., Odeyinka, H., McKeown, C. \& McNiff, S., BIM implementation throughout the UK construction project lifecycle: an analysis. Automation in Construction, 36(2013), pp. 145-151, 2013.

[9] Shenzhen Exploration \& Design Association (SZEDA), Guide for BIM application and development in the engineering \& design industry of Shenzhen, Tianjin Science \& Technology Press, Tianjin, pp. 15-44, 2013.

[10] Shanghai Construction Trade Association (SCTA) \& Luban Consulting, The annual 2014 investigation report of the current BIM application in construction firms, http://www.lubanway.com/index.php?controller= guandian\&action=guandian_front\&type=3\&guandian_id=439 